\author{
광산란법에서 실리카 졸의 농도 및 표면특성이 입자 크기 및 전기영동 이동도 \\ 측정결과에 미치는 영향 \\ 조경숙 $* * *$ 이동현 $* * *$ · 김대성* · 임형미* · 김종엽** · 이승호*, \\ *한국세라믹기술원 에너지환경소재본부 에코복합소재센터 \\ 153-801 서울시 금천구 디지털로 10 길 77 \\ **고려대학교 화공생명공학과 \\ 136-709 서울시 성북구 안암동 5 가 1
}

(2013년 1월 7일 접수, 2013년 6월 3일 수정본 접수, 2013년 7월 4일 채택)

\title{
Effect of Concentration and Surface Property of Silica Sol on the Determination of Particle Size and Electrophoretic Mobility by Light Scattering Method
}

\author{
Gyeong Sook Cho*,**, Dong-Hyun Lee*,**, Dae Sung Kim*, Hyung Mi Lim*, \\ Chong youp Kim** and Seung-Ho Lee*, ${ }^{*}$ \\ *Eco-Composite Materials Center, Energy Environment Materials Division, Korea Institute of Ceramic Engineering \& Technology (KICET), \\ 77 Digital-ro 10-Gil, Guemcheon-gu, Seoul 153-801, Korea \\ **Department of Chemical \& Biological Engineering, Korea University, 1 5-ga, Anam-dong, Sungbuk-gu, Seoul 136-701, Korea \\ (Received 7 January 2013; Received in revised form 3 June 2013; accepted 4 July 2013)
}

\section{요 약}

콜로이달 실리카는 실리콘과 사파이어 웨이퍼의 정밀연마슬러리, 유-무기 하이브리드 코팅제, 정밀주조의 바인더 등 다양한 제품으로 사용되는 물질이다. 이러한 실리카 졸의 입자크기 및 분산 안정성은 웨이퍼의 표면, 코팅 막 혹은 벌 크의 기계적, 화학적, 광학적 특성에 영향을 주기 때문에 정확한 측정값이 요구된다. 본 연구에서는 제조사에서 제시 한 입자 크기 및 표면 특성이 다른 8종류 실리카 졸의 부피 분율에 따라 입자 크기, 졸 점도 및 입자 전기영동이동도 의 측정결과에 미치는 영향을 논의하였다. 높은 표면활성을 지닌 실리카 입자의 특성 및 실리카 졸의 희석에 의한 안 정화 이온 농도의 변화로 인해 실리카의 측정 입자 크기와 이동도는 졸의 부피 분율 혹은 입자 크기에 따라 변한다. $60 \mathrm{~nm}$ 보다 작은 입자는 부피 분율이 증가함에 따라 측정된 입자 크기가 증가한 반면에, 그 보다 큰 입자에서는 측정 된 입자 크기가 감소하였다. $12 \mathrm{~nm}$ 와 같이 작은 입자는 부피 분율이 증가함에 따라 점도가 상승하면서 측정 입자의 이동도가 감소한 반면에 $100 \mathrm{~nm}$ 의 큰 입자는 0.048 의 낮은 부피 분율까지 이동도가 증가하다가 그보다 높은 부피 분 율부터 감소하였다.

\begin{abstract}
Colloidal silica is used in various industrial products such as chemical mechanical polishing slurry for planarization of silicon and sapphire wafer, organic-inorganic hybrid coatings, binder of investment casting, etc. An accurate determination of particle size and dispersion stability of silica sol is demanded because it has a strong influence on surface of wafer, film of coatings or bulks having mechanical, chemical and optical properties. The study herein is discussed on the effect of measurement results of average particle size, sol viscosity and electrophoretic mobility of particle according to the volume fraction of eight types of silica sol with different size and surface properties of silica particles which are presented by the manufacturer. The measured particle size and the mobility of these sol were changed by volume fraction or particle size due to highly active surface of silica particle and change of concentration of counter ion by dilution of silica sol. While in case the measured sizes of small particles less than $60 \mathrm{~nm}$ are increased with increasing volume fraction, the measured sizes of larger particles than $60 \mathrm{~nm}$ are slightly decreased. The mobility of small particle such as $12 \mathrm{~nm}$ are decreased with increase of viscosity. However, the mobility of $100 \mathrm{~nm}$ particles under 0.048 volume fraction are increased with increasing volume fraction and then decreased over higher volume fraction.
\end{abstract}

Key words: Silica Sol, DLS, Particle Size, Electrophoresis, Particle Mobility, Volume Fraction

\footnotetext{
${ }^{\dagger}$ To whom correspondence should be addressed.

E-mail: shlee@kicet.re.kr
} 


\section{1. 서 론}

콜로이달 실리카는 물 또는 유기용매에 규소산화물 입자가 안정 하게 분산된 상태의 소재로서 19세기 이후부터 다양한 산업분야에 사용되어왔다. 그 응용분야로서 세라믹 코팅제, 섬유, 유-무기 하이 브리드 코팅제, 식품제지 및 코팅의 첨가제, 섬유산업의 조제, 유리 섬유 가공, 요업재료, 내화 제품 및 절연물질, 단열재의 결합재, 촉 매제조의 원료, 반도체 웨이퍼 연마재, 토양 경화를 위한 화학적 그 라우팅 주입약재 등이 있다. 이전의 실리카 졸 응용에 있어서 입자 크기 및 표면전하 특성 제어가 중요하지 않았으나, 최근에는 반도 체 정밀가공을 위한 $\mathrm{CMP}$ 슬러리, 광학용 필름 혹은 렌즈의 광학특 성의 정밀 제어를 위한 기능성 나노 졸, 광 투광성을 제어하는 다양 한 기능성 유-무기하이브리드 코팅제 제조 등의 응용분야에 실리카 졸의 입자크기, 입도 분포, 입자 표면특성의 정밀한 측정에 의해 얻 어진 결과 값이 매우 중요하게 되었다.

입자 크기가 20 100 nm 범위의 실리카 졸은 반도체 웨이퍼, 반 도체 소자, 사파이어 웨이퍼, 실리카 웨이퍼 등의 정밀 연마에 널리 사용되고 있다. 큰 비표면적 및 약 5 30 nm의 입자 크기를 갖는 초 미세 실리카 졸은 종이 제조, 철강 표면 처리 및 기타 분야에 널리 사용된다. 그 중 종이 산업에서 작은 입자 크기로 인한 높은 접착강 도와 강한 결합력 및 큰 비표면적으로 인한 강한 정전기 방지 특성 때문에 매우 유용하게 사용되고 있다. 실리카 졸은 표면 특성에 따 라 산성, 중성 혹은 알칼리성의 수계가 있으며, 비수계의 극성에 따 라 알코올, MEK, MIBK 등의 여러 가지 유기 용매 실리카 졸이 있 다[1]. 졸 제품은 기본적으로 농도, 입자크기, $\mathrm{pH}$, 안정화 이온이 제 품규격으로 제시되고 있지만 졸의 제조일, 보관온도 등에 따라 크기 및 안정성이 변하고, 입도 및 입자 안정성의 평가는 측정 방법 및 측정자에 따라서도 편차를 보이고 있다. 따라서 제공된 졸의 정확 한 입도 및 제타전위를 측정하기 위하여 측정 시료의 준비 방법이나 졸 농도에 따른 입자 크기 및 이동도 변화에 대한 평가가 필요하다[2,3].

안정성이 높고 진구형이며 입도분포가 좁은 단분산 polystyrene 콜로이드 입자의 광자 상관법(PCS, photon correlation spectroscopy)에 의한 입도분석의 연구[4]는 많이 보고 되었으나 상업적으로 생산되 고 있는 콜로이드 실리카에 대한 연구는 비겨적 적었다. 실리카 입 자가 분산되어 있는 용액의 $\mathrm{pH}$, 입자의 표면특성, 입자 크기 및 졸 의 농도에 따라서 측정 장비의 검출 감도 및 각도가 달라지고, 입자 간의 인력에 의한 클러스터 혹은 응집에 점도가 변화하고 이러한 점 도 변화는 입자의 브라운 운동을 방해하여 입자 확산속도를 변화시 키므로 측정 입자 크기가 변한다.
Tantra 등 (2010)은 입도 및 제타전위 측정에 대한 콜로이달 실리 카, 다중벽 탄소나노튜브(bamboo-shaped and hollow nanotube), 금 등 의 4 가지 나노 입자에 따른 부피 분율(volume fraction)의 영향과 재 현성에 대하여 연구하였다[5]. 이 결과에 의하면 측정에 사용된 나노 입자들은 측정값이 안정적인 부피 분율 범위가 있으며, 희석함에 따 라 입도와 제타 전위의 값 및 그 편차가 크게 나는 불안정적인 부 피 분율 범위가 존재한다고 기술하고 있다. 또한, 입자의 종류에 따 라 입자가 구형이 아닐수록 불안정적인 부피 분율 범위에서 입도와 제타전위가 크게 차이가 있다고 보고하고 있다.

본 연구에서는 입자 크기 및 표면특성이 상이한 수계의 산성 및 염기성 실리카 졸 8종류에 대하여 부피 분율에 따른 졸 입자 크기, 점 도 및 입자의 전기영동 이동도 변화를 각각 측정하였다. 졸 부피 분 율 변화에 따라서 측정된 졸 입자 크기와의 상관성을 설명하고 졸 용액의 부피 분율 및 입자 크기가 입자의 전기영동 이동도에 미치는 영향에 대하여 연구하였다.

\section{2. 실 험}

\section{2-1. 실리카 졸 입자 크기 및 형상 측정}

다양한 부피 분율 범위에서 입자크기 및 표면특성이 다른 실리카 졸의 입도 및 입도 분포를 측정하였다. 실험에 사용된 8개의 실리 카 졸은 Table 1 에 제조사에서 제시한 입자 크기, $\mathrm{pH}$, 안정화 이온, 비 표면적과 본 연구에서 $5 \mathrm{wt} \%(0.023$ 의 부피 분율)로 희석하여 측정 한 평균 입경을 정리하였다. 실험에 사용한 실리카 졸의 $30 \mathrm{wt} \%$ 원 액을 $0.5,1,5,10,20,30 \mathrm{wt} \%(0.002,0.005,0.023,0.048,0.102$, 0.163 의 부피 분율)의 다양한 농도로 희석하였다. 희석된 시료들은 입도 분석기를 사용하여 평균입도 및 입도 분포를 측정하였다. 원 액인 실리카 졸은 증류수를 사용하여 희석하였으며, 희석 시료의 $\mathrm{pH}$ 를 원액과 동일하게 유지하기 위하여 $\mathrm{KOH}$ 혹은 $\mathrm{HCl}$ 를 사용하여 조절하였다. 이 희석 시료는 1 시간 교반 후, 기포 제거를 위하여 1 분 간 초음파 처리하였다.

측정 시 온도의 변화로 인한 점도 및 확산계수의 측정오차를 최소

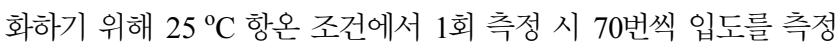
하고, 이 과정을 총 4회 반복하여 측정된 평균값을 사용하였다.

입도분석은 ELS-Z (Otsuka Electronics, Japan) 장비를 사용하였 으며, 동적광산란(DLS, Dynamic light scattering) 법으로부터 광자 상관법과 stoke-einstein 식을 사용하여 입도를 계산하였다. 또한 질 량 분율인 농도는 아래의 식 (1)과 같이 부피 분율(volume fraction) 로 계산하였으며, $\rho_{\text {sus }}$ 는 식 (2)을 사용하여 구하였다[6].

Table 1. Supporting information of the various commercial silica sols and the particle size measured by DLS

\begin{tabular}{|c|c|c|c|c|c|c|c|c|}
\hline \multirow{2}{*}{$\begin{array}{c}\text { Sample } \\
\text { name }\end{array}$} & \multicolumn{2}{|c|}{ Particle size (nm) } & \multirow[b]{2}{*}{$\mathrm{pH}$} & \multicolumn{2}{|c|}{ Counter ion } & \multirow{2}{*}{$\begin{array}{c}\text { BET } \\
\left(\mathrm{m}^{2} / \mathrm{g}\right)\end{array}$} & \multirow[b]{2}{*}{ Product code } & \multirow[b]{2}{*}{ Supplier } \\
\hline & $\begin{array}{l}\text { Provided by } \\
\text { Manufacturer }\end{array}$ & Measured by DLS & & Type & Content (wt $\%)$ & & & \\
\hline $\mathrm{Lu} 7$ & 7 & 19 & 10 & $\mathrm{Na}$ & 0.56 & 345 & SM-30 (Ludox) & Aldrich \\
\hline Lu 12 & 12 & 18 & 9.7 & $\mathrm{Na}$ & 0.41 & 220 & HS-40 (Ludox) & Aldrich \\
\hline NC 15 & $10 \sim 20$ & 43 & $8.5 \sim 9$ & $\mathrm{Na}$ & $0.2 \downarrow$ & 218 & ST-C (SNOWTEX) & Nissan Chemical \\
\hline SC 25 & $20 \sim 30$ & 28 & $9 \sim 10$ & $\mathrm{Na}$ & 0.16 & 128 & SS-sol 30F & S-chemtech \\
\hline SC 100 & $90 \sim 110$ & 98 & $10 \sim 12$ & $\mathrm{~K}$ & $0.4 \downarrow$ & 27 & SS-sol 100 & S-chemtech \\
\hline $\mathrm{Lu}-\mathrm{CL}$ & 12 & 103 & 4.5 & $\mathrm{Cl}$ & $0.5 \downarrow$ & 230 & CL (Ludox) & Aldrich \\
\hline $\mathrm{NC} 45$ & $40 \sim 50$ & 65 & $2 \sim 4$ & $\mathrm{Na}$ & $0.04 \downarrow$ & 60 & ST-OL (SNOWTEX) & Nissan Chemical \\
\hline
\end{tabular}




$$
\begin{aligned}
& \Phi=w \rho_{\text {sus }} / \rho_{p} \\
& \rho_{\text {sus }}=\rho_{e} \frac{1}{1+w\left(\frac{\rho_{e}}{\rho_{p}}-1\right)}
\end{aligned}
$$

여기서 $\Phi$ 는 부피분율, $w$ 는 실리카 졸의 농도, $\rho_{s u s}$ 는 용액의 밀도, $\rho_{p}$ 는 실리카의 밀도 $\left(2.2 \mathrm{~g} / \mathrm{cm}^{3}\right), \rho_{e}$ 는 물의 밀도 $\left(1.0 \mathrm{~g} / \mathrm{cm}^{3}\right)$ 이다.

실험에 사용된 입자의 형상은 TEM (Transmission Electron Microscopy, $\mathrm{JEM}-2000, \mathrm{JEOL})$ 을 사용하여 관찰하였으며, 시료는 입도분석에 사 용된 것과 동일한 방법으로 준비하였다. 준비된 시료는 TEM grid (carbon-coated 200mesh copper grid)에 한 방울 떨어뜨리고 $60{ }^{\circ} \mathrm{C}$ 오븐에서 6시간 이상 건조시켜 남아있는 용매를 모두 제거하였다. $\mathrm{TEM}$ 측정은 200,000 배 및 500,000 배의 배율로 시료를 관찰하였다.

\section{2-2. 실리카 졸의 전기영동 이동도(electrophoretic mobility) 측정}

졸 입자의 전기영동 이동도를 측정하기 위한 시료는 2-1에서 입 자 크기 측정과 같은 방법으로 제조하였다. 가능한 측정 간의 입자 이동도의 오차를 줄이기 위하여 샘플 중앙(cell center)을 Z축에 정 확히 맞추었다. 이동도는 입도 분석장비와 같은 ELS-Z를 사용하여 측정하였다. 또한, 신뢰도를 향상하기 위하여 총 4 회 반복하여 측정 된 평균값을 사용하였으며, 졸 용액에 걸어준 $70 \mathrm{Volt}$ 의 전장에 대 한 입자의 이동도는 유체 흐름의 정지면에서 측정된 값이다.

\section{2-3. 실리카 졸 점도 측정}

부피 분율 변화와 시료의 특성에 따른 응집(agglomeration or aggregation)을 확인하기 위하여 점도를 측정하였다. 점도를 측정하 기 위한 시료는 2-1의 입자 크기 측정 시료와 같다.

측정 장비는 진동식 점도계인 SV-10 (A\&D, Japan)을 사용하였 다. 측정 시 온도의 변화로 인한 점도 변화를 줄이기 위하여 $25{ }^{\circ} \mathrm{C}$ 항온조건에서 총 3 회 측정 후 평균값을 사용하였다.

\section{3. 결과 및 고찰}

\section{3-1. 실리카 졸 입자의 크기 및 부피 분율과 측정된 입자 크기의 상관성}

Table 1에 정리된 8종류의 다양한 실리카 졸에 대한 입자의 TEM 이미지를 Fig. 1에 나타내었다. TEM 이미지의 실리카 입자 크기는 각 제조사에서 제시한 자료와 거의 일치함을 보여준다. 입도분석기 로 측정한 평균 입자 크기와 제조사에서 제시한 입자 크기를 비교 할 경우 SC $25, \mathrm{YC} 60, \mathrm{SC} 100$ 및 $\mathrm{NC} 45$ 와 같이 비교적 큰 입자의

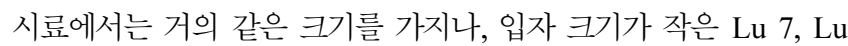
$12, \mathrm{NC} 15$ 및 Lu-CL의 시료는 서로 입자 크기 차이가 크게 나타난 다. TEM에서 보여준 바와 같이 입자 크기가 작은 졸 시료에서는 동 일 부피 분율에서 큰 입자 크기의 시료보다 입자 농도가 증가하기 때문에 입자간 거리가 가까워져 응집이 생성된 것으로 보인다. 특 히 $\mathrm{Lu}-\mathrm{CL}$ 시료는 제조사가 제시한 입자 크기가 $12 \mathrm{~nm}$ 인 반면에 입 도분석기에 의해 측정된 입자 크기는 $103 \mathrm{~nm}$ 로서 입자 간 크기 차 이가 9배 정도로 크게 나타는데[7] 이는 입자 크기가 작을 뿐만 아 니라 용액의 $\mathrm{pH}$ 영역이 4 5로서 다른 졸의 $\mathrm{pH}$ 영역보다 불안정하 기 때문에 졸 용액 내에 입자가 응집 입자로 존재하여 입자가 크게 측정된 것으로 생각된다. Fig. 3에서 나타냈듯이, 동일 부피 분율에
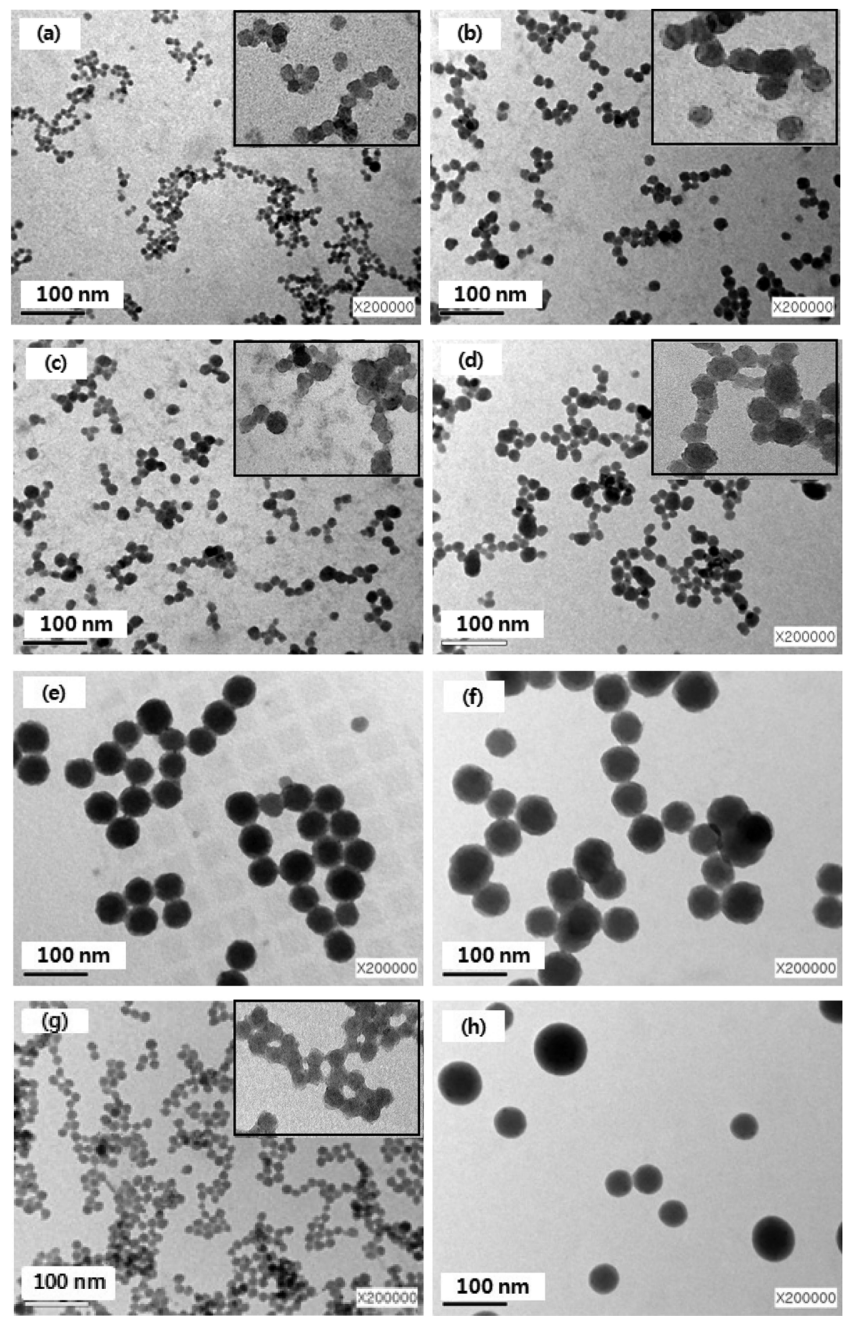

Fig. 1. TEM images of 8 kinds of commercial silica sol; (a) Lu 7, (b) Lu 12, (c) NC 15, (d) SC 25, (e) YC 60, (f) SC 100, (g) Lu-CL, and (h) NC 45.

서 $\mathrm{Lu}-\mathrm{CL}$ 의 점도가 다른 실리카 졸인 $\mathrm{Lu} 12, \mathrm{NC} 45, \mathrm{YC} 60, \mathrm{SC}$ 100 과 비교하여 5 9배 더 높게 나온 것으로부터 Lu-CL의 용액 내에 입자의 응집성이 가장 큰 것을 예상할 수 있다.

높은 부피 분율인 실리카 졸 원액의 입도를 입도분석기로 측정할 때에 일반적으로 졸을 증류수로 $1 \mathrm{wt} \%$ 이하로 희석하여 측정하지 만 실리카 졸의 종류나 입자의 크기에 따라서 희석 방법이나 시료 의 부피 분율에 대한 표준은 아직 없다. 이는 $100 \mathrm{~nm}$ 이하의 졸을 동적광산란 방법으로 측정 시 시료의 종류에 따라서 그 측정 편차 가 크게 나타나기 때문이다. 이러한 편차에 대한 것을 조사하기 위 하여 입자 크기 혹은 안정화 이온이 다른 6 종류의 졸 시료에 대하 여 $0.002 \sim 0.163$ 의 부피 분율 범위에서 평균 입자 크기를 측정하여 Fig. 2에 나타내었다. 염기성이고 제조사에서 제공한 입자 크기가 비교적 큰 $60 \mathrm{~nm}$ 의 $\mathrm{YC} 60,100 \mathrm{~nm}$ 의 SC 100 은 낮은 부피 분율인 0.002 에서 원액인 0.163 의 높은 부피 분율까지 평균 입자 크기가 $\mathrm{YC} 60$ 은 $32 \%, \mathrm{SC} 100$ 은 $11 \%$ 가 감소하였다. 이는 부피 분율이 증 가함에 따라 입자 주변에 안정화 이온, 즉 $\mathrm{K}$ 함량이 높아지기 때문 에 입자 주위의 전기이중층의 압축에 따른 입자 크기 감소에 기인 한 것으로 보인다. 제조사에서 제시한 입자크기가 큰 입자의 경우 낮은 부피 분율에서는 졸이 증류수에 희석되어 안정화 이온의 함량 


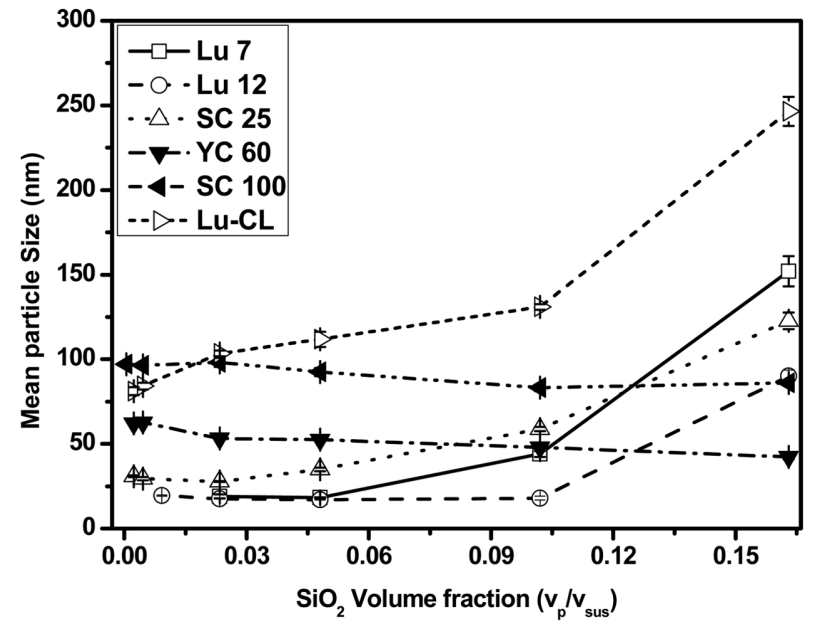

Fig. 2. Mean particle size depending on the $\mathrm{SiO}_{2}$ volume fraction for various silica sol with difference size and surface property. (small particle below $60 \mathrm{~nm}$ : opened symbol, large particle above $60 \mathrm{~nm}$ : filled symbol).

이 낮아지기 때문에 전기이중층의 밀도는 낮아지며 두께는 팽창하 게 되지만 원액 상태의 졸에서는 안정화 이온이 농후하기 때문에 입 자의 전기이중층의 밀도는 높아져 두께는 얇아진다. 따라서, 부피 분율이 증가함에 따라 안정화 이온의 함량이 많아지고 입자 주변의 전기이중층이 압축되었기 때문에 유체역학적 반경(hydrodynamic diameter)을 측정하는 동적광산란 방법으로는 부피 분율이 증가함 에 따라 입자 크기가 감소된 것으로 측정된다[8,9]. 그러나 제조사 에서 제시한 입자 크기가 작은 $\mathrm{Lu} \mathrm{7,} \mathrm{Lu} \mathrm{12,} \mathrm{SC} 25$ 및 $\mathrm{Lu}-\mathrm{CL}$ 의 부피 분율이 증가함에 따라 입자 크기는 지수 함수적으로 증가하였 으며 입자의 크기가 작을수록 졸의 점도 증가율이 컸다. 이는 작은 크기 입자와 큰 입자가 3 배의 크기 차이가 있다면 동일 부피 분율 에서 개수는 27 배, 비표면적은 9 배 차이가 나므로 입자가 졸 용액 에서 차지하는 부피는 같지만 졸 입자의 개수 및 비표면적이 상대 적으로 커서 입자 간의 거리가 더욱 더 가까워지고 한 입자의 전기 이중층이 주위 입자에 영향을 주어서 입자 무리(particle crowding) 가 발생할 뿐만 아니라[10], 수력학적 상호작용에 의해 약하게 응집 된 입자(tagged particle)가 발생한다[11]. 따라서 이러한 응집된 입 자는 브라운 운동을 하는 개별 입자보다는 확산 속도가 감소하게 되 고 확산계수가 감소한다. 결국 입자 크기를 계산하는 stoke-einstein 식인 식 (3)에서 입자의 크기가 확산 계수에 반비례하므로 높은 부 피 분율인 졸 용액에서 입자 크기가 커지는 계산 결과를 나타낸다.

$$
\mathrm{R}_{h}=\frac{\mathrm{kT}}{6 \pi \eta \mathrm{D}}
$$

여기서 $\mathrm{R}_{h}$ 는 수력학적 반경, $\mathrm{k}$ 는 볼츠만 정수, $\mathrm{T}$ 는 절대 온도, $\eta$ 는 용매의 점도, $\mathrm{D}$ 는 확산 계수이다.

\section{3-2. 졸 입자의 크기 및 부피 분율에 대한 입자의 전기영동 이 동도의 영향}

염기성 실리카 졸 $\mathrm{Lu} 12, \mathrm{YC} 60$ 및 SC 100과 산성 실리카 졸 $\mathrm{Lu}-\mathrm{CL}$ 및 $\mathrm{NC} 45$ 의 부피 분율의 증가에 따라 입자의 전기영동 이 동도를 측정하고 Fig. 3(a), (b)에 각각 나타내었다.

Fig. 3(a)에서 보는 바와 같이 염기성이며 $12 \mathrm{~nm}$ 입자 크기인 $\mathrm{Lu}$
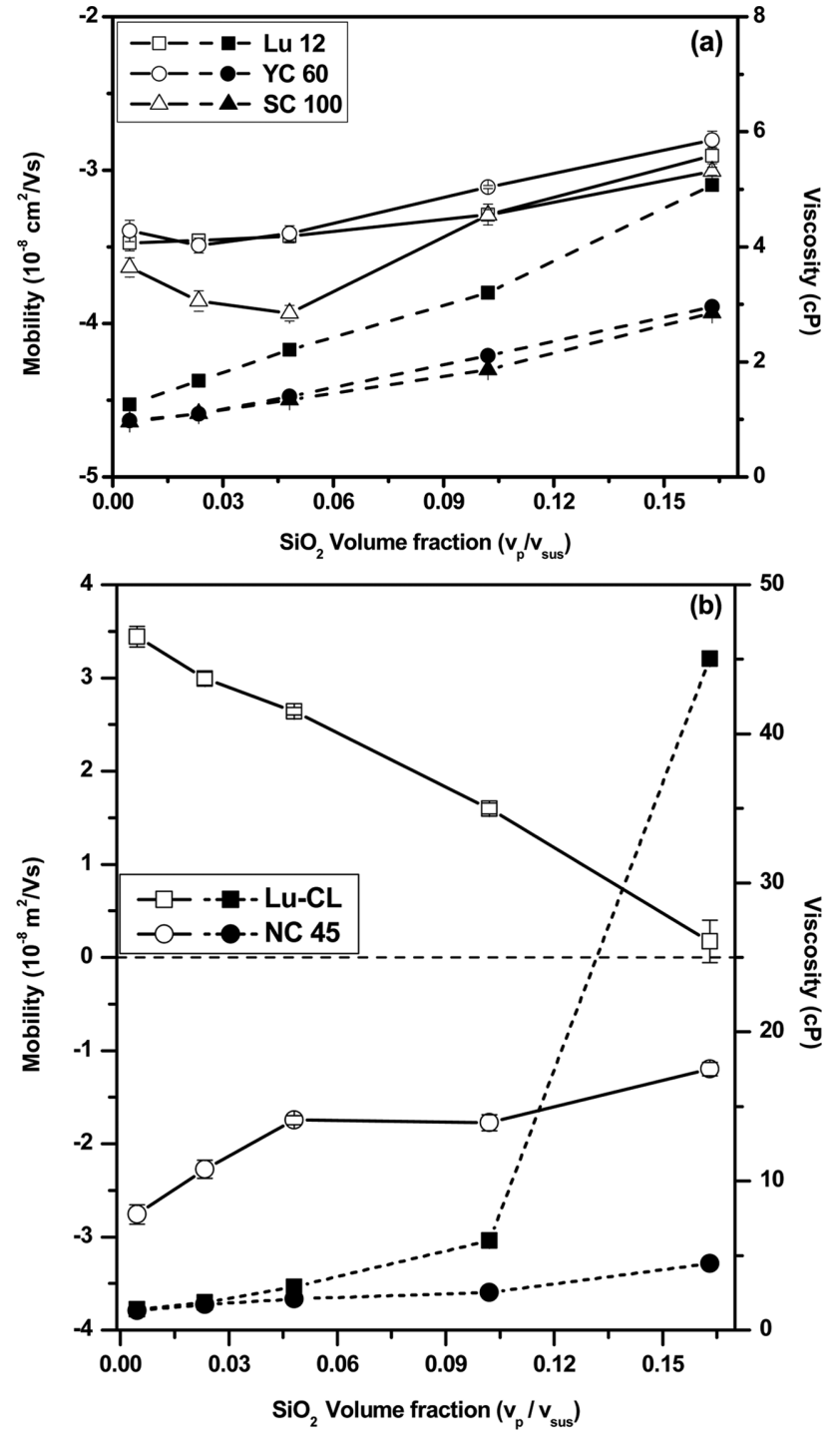

Fig. 3. Particle electrophoretic mobility $(\mu)$ and sol viscosity $(\eta)$ depending on the $\mathrm{SiO}_{2}$ volume fraction of silica sols; (a) alkali silica sol, (b) acid silica sol (mobility : opened symbol, viscosity : filled symbol).

$12,60 \mathrm{~nm}$ 크기인 YC 60 및 90 110 nm 크기인 SC 100은 부피 분 율의 증가에 따라 점도는 비례적으로 증가하고 입자 이동도는 감소 하였다. $12 \mathrm{~nm}$ 크기의 작은 입자인 $\mathrm{Lu} \mathrm{12}$ 는 낮은 부피 분율에서 높 은 부피 분율로 증가함에 따라 입자 이동도가 서서히 감소한 것으 로 나타났으며, $60 \mathrm{~nm}$ 크기의 YC 60은 0.005 0.023 구간의 부피 분율에서는 이동도가 약간 증가하고 $0.023 \sim 0.163$ 구간에서는 이동 도가 감소하였다. 또한, 가장 큰 입자인 $100 \mathrm{~nm}$ 크기의 SC 100 은 0.005 0.048 부피 분율에서는 입자 이동도가 증가하고 0.048 0.163의 부피 분율에서는 입자 이동도가 감소하였다.

앞에서 설명한 바와 같이 입자 크기가 다를 때 부피 분율의 증가에 따라서 다소 다른 이동도 경향을 나타내었다. 입자 크기가 작은 $\mathrm{Lu}$ 12 는 낮은 부피 분율 영역에서 안정화 이온의 농도 증가에 따른 전 기 이중층 두께의 변화가 작아서 입자의 흐름에 큰 영향이 없고 각 입자 간 거리가 충분히 멀어 개별 입자로 작용하여 비교적 잘 분산 되어 있다. 하지만 높은 부피 분율에서는 입자 간 거리가 가까워짐 
으로 인하여 van der waals 힘 및 hydrodynamic 인력 작용에 의해 응집 입자가 생성되며 졸의 점도가 높아지게 된다. 이와 같이 생성 된 응집 형태의 입자는 이동도 측정 셀 내에서 전기영동 될 때 개 별 입자보다 더 많은 유체 저항을 받으며 전기장(electric field)과 수 평방향으로 원활히 흐르지 않기 때문에 실제 이동경로가 더 길어지 게 되어 전기 이동도가 낮아지게 된다[12]. 용매 내의 입자의 이동 도는 smoluchowski 식인 식 (4)로부터 제시된 바와 같이 입자 크기 및 부피 분율에는 무관한 함수이다. 하지만 앞에서 설명된 바와 같 이 측정 셀 내의 입자 이동에 대한 저항의 증가, 즉 졸 점도의 증가 로 인하여[13] 입자의 전기영동 이동도가 낮아진다.

$$
\mu=\frac{\xi \varepsilon}{\eta}
$$

여기서 $\mu$ 는 전기영동 이동도, $\xi$ 는 제타전위, $\varepsilon$ 는 유전상수, $\eta$ 용매의 점도이다. 즉, 입자의 형상에 따라 입자 이동도의 감소율에 차이가 있으며 졸의 점도는 입자의 전기영동 이동도에 큰 영향을 준다. 또한, 졸 농도가 증가함에 따라 안정화 이온의 농도도 증가하게 되 는데 V. Lobaskin 등(2007)의 연구에 의하면 전해질의 농도가 높아짐 에 따라 입자의 이동도가 떨어진다고 한다[14]. 입자 크기가 큰 60 $\mathrm{nm}$ 이상의 YC 60에서는 낮은 부피 분율에서 이동도가 증가하다가 부피 분율이 더 증가하면 앞에서 설명한 바와 같이 이동도가 감소 하였다. 입자 크기가 가장 큰 SC 100 에서는 이러한 경향이 뚜렷하 게 나타난다. 이러한 원인으로서는 졸이 낮은 부피 분율에서는 이중 층 압축에 의한 크기 감소로 입자 흐름이 증진되기 때문에 입자 이 동도가 증가하지만 부피 분율이 증가하면 입자 간의 응집에 의한 점 도 상승 효과에 의한 이동도 감소가 커지기 때문에 이동도가 감소 하는 것으로 보인다. Fig. 3(b)에서는 산성 졸인 Lu-CL과 NC 45의 부피 분율이 증가함에 따라 이동도의 절대 값이 모두 감소하였다. 그 감소율은 입자가 더 작은 Lu-CL에서 컸고 가장 부피 분율이 높 은 0.163 에서 거의 0 에 가까운 이동도 값을 나타내었다. Lu-CL은 음전하인 실리카 표면에 양전하인 알루미늄 수산화물 혹은 산화물 로 표면 개질된 $\mathrm{pH}$ 4 5의 졸로서 염기성 졸에 비하여 안정성이 낮 고 입자 크기가 작아 응집 입자가 $\mathrm{Lu} \mathrm{12보다} \mathrm{더} \mathrm{크게} \mathrm{형성되어} \mathrm{입}$ 자 이동도의 감소율이 더 큰 것으로 생각된다. $\mathrm{Lu}-\mathrm{CL}$ 에 비해 큰 입 자인 $\mathrm{NC} 45$ 의 부피 분율에 따른 입자 이동도도 $\mathrm{Lu}-\mathrm{CL}$ 과 유사한 감 소 거동을 나타냈다. NC 45 졸은 산성에서 안정화하기 위하여 일 반 염기성 실리카 졸보다 안정화 이온의 농도가 $1 / 10$ 정도 낮다. 안 정화 이온 농도가 낮아 졸의 안정성은 낮지만 입자 크기가 Lu-CL 보다 크기 때문에 Lu-CL의 입자 이동도보다는 감소율이 낮은 것으 로 생각된다.

산성 졸과 염기성 졸의 응집성에 대한 비교는 점도 그래프에서 확인 할 수 있었다. 산성 졸인 $\mathrm{Lu}-\mathrm{CL}$ 졸은 같은 크기의 염기성 졸 인 $\mathrm{Lu} 12$ 보다 점도가 9배가 더 크며, 약 $45 \mathrm{~nm}$ 크기의 산성 졸인 $\mathrm{NC} 45$ 는 $12 \mathrm{~nm}$ 의 염기성 졸인 $\mathrm{Lu} 12$ 보다 크기가 4배 크지만 점 도는 비슷하게 나왔다. 본래 0.100 이상의 높은 부피 분율의 입자의 경우, 부피 분율의 증가에 따라 점도는 Dougherty-Krieger model에 의해 지수함수적으로 증가한다.

$$
\eta=\eta_{s}\left(1-\Phi / \Phi_{m}\right)^{-[\eta] \Phi_{m}}
$$

여기서 $\eta$ 는 용액의 점도, $\eta_{s}$ 는 용매의 점도, $\Phi$ 은 부피 분율, $\Phi_{m}$ 은 최대 부피 분율, $[\eta]$ 은 고유 점도이다. 입자의 비대칭성은 고유 점

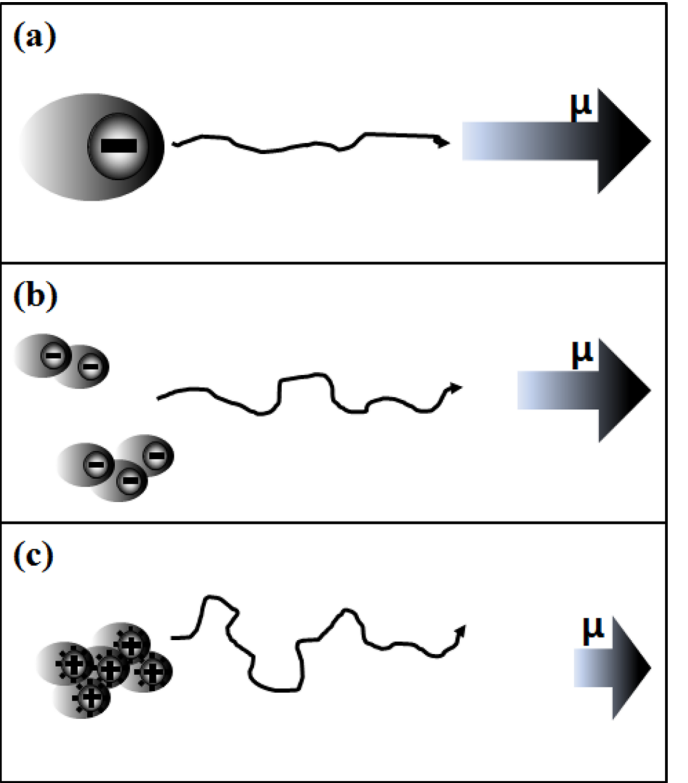

Fig. 4. Schematic illustration of the particle electrophoretic mobility $(\mu)$ depending on the particle size and surface property under the volume fraction; (a) large particle, (b) small particle, (c) small particle with surface coating.

도와 최대 충전 분율에 큰 영향을 주어, 식 (5)에 의하여 입자의 비 대칭성이 클수록 같은 부피 분율에서 점도는 크게 증가한다[15]. 이 와 같은 관점에서 같은 크기의 입자에 대해, $\mathrm{Lu}-\mathrm{CL}$ 과 $\mathrm{Lu} 12$ 는 입 자간의 작용력이 비슷하여 점도 값도 유사하여야 하지만 Lu-CL이 더 높게 나온 것으로 보아 졸 용액 내에 응집 입자가 더 많이 혹은 더 크게 존재한 것으로 보인다. 또한, 다른 크기의 입자에 대해서는 입자 크기에 따라 입자 간 상호 작용력이 다르게 나타나며 일반적 으로 작은 입자일 때 입자 간 인력이 더 크게 작용하여 점도가 더 크게 나온다. 하지만, 염기성 졸인 Lu 12와 산성 졸인 NC 45는 입 자 크기가 4 배의 차이에도 불구하고 점도가 비슷하게 나온 것으로 보아 NC 45가 큰 입자임에도 불구하고 산성영역에서 안정화 이온 의 농도가 $\mathrm{Lu} 12$ 에 비해서 $1 / 10$ 수준으로 낮기 때문에 응집 입자가 크게 형성된 것으로 생각된다. 그러므로 산성졸인 $\mathrm{NC} 45$ 응집 효 과와 작은 크기의 염기성 졸인 $\mathrm{Lu} \mathrm{12}$ 의 응집효과가 비슷하여 부피 분율 증가에 대한 점도 상승율이 비슷하게 나타난다는 것을 알 수 있다.

이러한 다양한 크기의 입자와 표면 특성이 다른 입자가 전기영동 이동도에 미치는 영향에 대하여 Fig. 4에 도식적으로 표현하였다. Fig. 4에서 (a)는 응집 입자가 없고 음전하를 가진 큰 입자로서 이동 도가 가장 높고, (b)는 약간의 응집 입자가 있고 음전하를 가진 작 은 입자로서 이동도가 낮으며, (c)는 표면처리로 인해 양전하를 가 지는 응집 입자로서 유체 저항이 가장 크기 때문에 움직임이 매우 느려서 이동도가 가장 낮다는 것을 표현하였다. 앞에서 설명한 시 료를 이러한 그림에 적용하면 (a)는 SC 100 (b)는 $\mathrm{Lu} 12$ 그리고 (c) 는 $\mathrm{Lu}-\mathrm{CL}$ 시료의 이동도 특성을 각각 의미한다. 우리는 앞에서 입 자 크기가 작은 졸은 입자의 부피 분율이 증가하면 입자의 응집이 증가한다고 설명을 하였다. 이러한 응집성을 확인하기 위해 $12 \mathrm{~nm}$ 인 $\mathrm{Lu} \mathrm{12}$ 의 부피 분율 변화에 따른 입도 분포 변화를 Fig. 5 에 나 타내었다. 그래프에서 보는 바와 같이 졸의 낮은 부피 분율인 0.023 및 0.048 에서 두 개의 입도분포 peak가 나타났으며, 높은 부피 분

Korean Chem. Eng. Res., Vol. 51, No. 5, October, 2013 


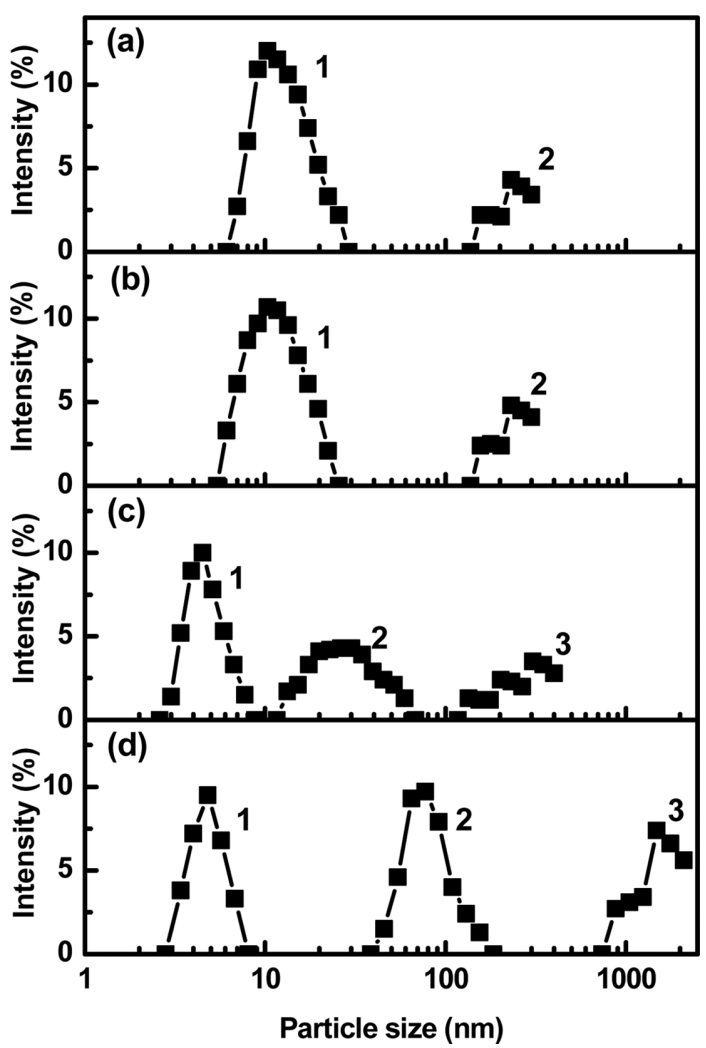

Fig. 5. Effect of volume fraction of silica sol Lu 12 on the particle size distribution as a function of particle size and intensity; volume fraction (a) 0.023 , (b) 0.048 , (c) 0.102 , (d) 0.163 .

율인 0.102 및 0.163 에서 세 개의 입도분포 peak가 나타났다. 부피 분율의 증가에 따라 입도 분포에서 peak 위치가 큰 입자 측으로 이 동하고 큰 입자의 비율이 증가하였으며, 이러한 큰 입자는 응집된 입자를 나타낸다. 응집된 큰 입자는 졸 점도를 증가시키고 결과적 으로 입자 이동도를 감소하게 하는 원인이 되었다.

상기에서 설명한 바와 같이 실리카졸의 부피 분율에 따른 입자의 이동도의 영향에 대해 토의한 결과 입자 이동도는 입자의 크기, 안 정화 이온의 농도, 졸의 $\mathrm{pH}$ 및 졸의 부피 분율에 따라 큰 차이가 발 생하므로 제시된 졸 시료와 측정시료의 상태 혹은 물성을 정확히 파 악함으로서 신뢰성 있는 측정 결과 값을 얻을 수 있다.

\section{4. 결 론}

본 연구에서는 다양한 입자 크기 및 표면특성을 갖는 콜로이달 실리카의 부피 분율에 따라 입자의 크기 및 전기영동 이동도를 측 정하였다. 제조사에서 제시한 입자 크기가 큰 실리카 졸과 작은 실 리카 졸의 부피 분율에 따라 측정한 입자 크기의 변화는 반대의 경 향을 나타냈다. 작은 크기의 졸은 부피 분율이 증가하면 입자들 간 의 응집의 영향으로 측정 크기가 크게 증가한 반면에 큰 크기의 졸 은 입자의 전기이중층 두께의 압축으로 인해 입자 크기가 약간 감 소하였다. 졸의 일차 입자 크기가 작을수록 부피 분율이 증가함에 따라 더 큰 응집으로 인하여 측정 입자 크기의 증가율이 더 높았다. 전 반적으로 졸의 부피 분율이 증가함에 따라 입자 간의 상호 작용에 의한 응집 현상으로 전기영동 이동도가 감소하였다. 염기성 졸에서
는 입자의 전기이중층 압축과 입자 간의 응집이 입자 이동도에 영 향을 주었다. 제조사에서 제시된 입자 크기가 작은 졸은 입자들 간 의 응집의 영향이 크기 때문에 이동도가 감소한 반면에 입자 크기 가 큰 졸은 낮은 부피 분율에서는 입자 간의 응집보다는 전기이중 층의 두께의 압축 영향이 커서 이동도가 증가하다가 졸의 부피 분 율이 높아지면 입자의 응집 영향이 커서 입자 이동도가 감소하였다.

\section{감 사}

본 연구는 한국세라믹기술원의 시험분석 평가인증분야 기반구축 사업으로 수행되었으며 이에 감사드립니다.

\section{References}

1. Changjin, C., "China Silicon Industry,' 3(6), 14-15, CRCSI, China (2010).

2. Cintre, M., Cambon, S., Leclerc, D. and Dodds, J., "Sizing Synthetic Mixtures of Latex and Various Colloidal Suspensions by Photon Correlation Spectrometry," Anal. Chem, 58, 86-90(1986).

3. R. Xu, "Progress in Nanoparticles Characterization : Sizing and Zeta Potential Measurement,' Particuology, 6, 112-115(2008).

4. Jaeger, N., Demeyere, H., Finsy, R., Sneyers, R., Vanderdeelen, J., Meeren, P. and Laethem, M., "Particle Sizing by Photon Correlation Spectroscopy. Part I: Monodisperse Latices: Influence of Scattering Angle and Concentration of Dispersed Material,' Part. Part. Syst. Charact, 8, 179-186(1991).

5. Tantra, R., Schulze, P. and Quincey, P., "Effect of Nanoparticle Concentration on Zeta-potential Measurement Results and Reproducibility,' Particuology, 8, 279-285(2010).

6. Adamczyk, Z., Jachimska, B. and Kolasinska, M., "Structure of Colloid Silica Determined by Viscosity Measurements,' J. Colloid interface Sci., 273, 668-674(2004).

7. Viota, J. L., Rasa, M., Sacanna, S. and Philipse, A. P., "Stability of Mixtures of Charged Silica, Silica-alumina, and Magnetite Colloids," J. Colloid Interface Sci., 290, 419-425(2005).

8. ISO Reference, "Particle Size Analysis-Photon Corelation Spectroscopy,' ISO 13321(1996).

9. DLS technical note MRK656-01, Malvern Instruments Ltd.

10. Paik, U., Kim, J. Y. and Hackley, V. A., "Rheological and Electrokinetic Behavior Associated with Concentrated Nanosize Silica Hydrosols," Mater. Chem. Phys. 91, 205-211(2005).

11. Quemada, D. and Berli, C., "Energy of Interaction in Colloids and Its Implications in Rheological Modeling," Adv. Colloid interface Sci., 98, 51-85(2002).

12. O'Brien, R. W. and White, L. R., "Electrophoretic Mobility of a Spherical Colloidal Particle,' J. Chem. Soc. Farad. Trans. II, 74, 1607-1626(1978).

13. Mondragon, R., Julia, J. E., Barba, A. and Jarque, J. C., "Determination of the Packing Fraction of Silica Nanoparticles from the Rheological and Viscoelastic Measurements of Nanouids,' Chem. Eng. Sci, 80, 119-127(2012).

14. Lobaskin, V., Dünweg, B., Medebach, M., Palberg, T. and Holm, C., "Electrophoresis of Colloidal Dispersions in the Low-salt Regime,' Phys. Rev. Lett., 98, 176105-1 176105-2(2007).

15. Barnes, H. A., Hutton, J. F. and Walters, K., "An Introduction to Rheology," Rheology Series 3, 120 125, Elsevier(1989). 